Document downloaded from:

http://hdl.handle.net/10251/52480

This paper must be cited as:

El Sayed Shehata Nasr, S.; De La Torre Paredes, C.; Santos Figueroa, LE.; Martínez Mañez, R.; Sancenón Galarza, F.; Costero Nieto, AM.; Gil, S.... (2015). Azide and sulfonylazide functionalized fluorophores for the selective and sensitive detection of hydrogen sulfide. Sensors and Actuators B: Chemical. 207(B):987-994.

doi:10.1016/j.snb.2014.04.047.

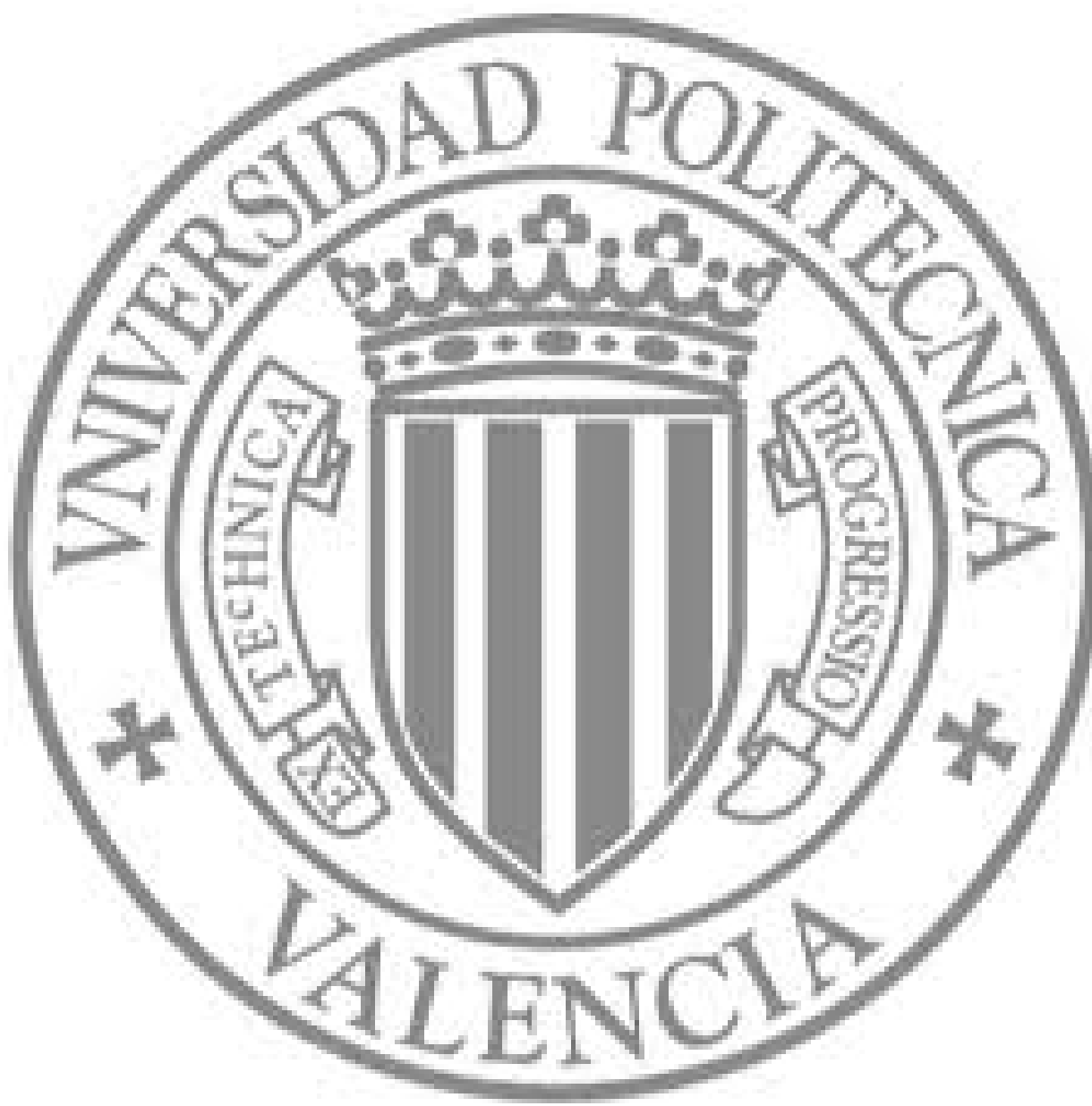

The final publication is available at

http://dx.doi.org/10.1016/j.snb.2014.04.047

Copyright Elsevier 


\title{
Azide and sulfonylazide functionalized fluorophores for the selective and sensitive detection of hydrogen sulfide
}

\author{
Sameh Elsayed, ${ }^{[a, b, c]}$ Cristina de la Torre,${ }^{[a, b, c]}$ Luis E. Santos-Figueroa, ${ }^{[a, b, c]}$ Cristina \\ Marín-Hernández, ${ }^{[\mathrm{a}, \mathrm{b}, \mathrm{c}]}$ Ramón Martínez-Máñez, ${ }^{*[\mathrm{a}, \mathrm{b}, \mathrm{c}]}$ Félix Sancenón, ${ }^{[\mathrm{a}, \mathrm{b}, \mathrm{c}]}$ Ana M. \\ Costero, ${ }^{*[a, d]}$ Salvador Gil ${ }^{[a, d]}$ and Margarita Parra ${ }^{[a, d]}$
}

\author{
[a] Centro de Reconocimiento Molecular y Desarrollo Tecnológico (IDM). Centro Mixto de la Universitat Politècnia de València y de la Universitat de \\ València. \\ [b] Departamento de Química. Universitat Politècnica de València. Camino de Vera s/n, 46022, Valencia, Spai. E-mail: rmaez@qim.upv.es \\ [c] CIBER de Bioingeniería, Biomateriales y Nanotecnología (CIBER-BNN). \\ [d] Departamento de Química Orgánica. Facultad de Ciencias Químicas. Universitat de València. Dr. Moliner 50, 46100, Burjassot, Valencia, Spain. E-mail: \\ ana.costero@uv.es
}

Keywords: hydrogen sulfide $\bullet$ fluorescence $\bullet$ azide $\bullet$ sulfonylazide $\bullet$ in vivo detection

\begin{abstract}
:
Three fluorescent probes (1-3) for the selective and sensitive detection of hydrogen sulfide have been synthesized and characterized. Probe $\mathbf{1}$ is a coumarin derivative functionalized with an azide moiety whereas $\mathbf{2}$ contain the azide reactive group into a naphthalene fluorophore backbone. Probe $\mathbf{3}$ is composed also by a naphthalene fluorophore but, in this case, functionalized with a sulfonylazide reactive moiety. Probes $\mathbf{1}$ and $\mathbf{3}$ are non-fluorescent whereas $\mathbf{2}$ is weakly emissive in HEPES (10 mM, pH 7.4)-DMSO 99:1 v/v. The emission behavior of the three probes was tested against selected anions, bio-thiols and oxidant molecules. Of all the chemical species tested, only $\mathrm{HS}^{-}$is able to induce an enhancement in the emission intensity (50,11 and 20-fold for 1, 2 and 3 respectively). The observed emission in the presence of hydrogen sulfide is ascribed, in the case of probes $\mathbf{1}$ and $\mathbf{2}$, to an azide-amine reduction induced by $\mathrm{HS}^{-}$anion, whereas for probe $\mathbf{3}$ the sensing mechanism is related with a sulfonylazide-sulfonamide conversion. The three probes are very sensitive to HS anion with limits of detection of $0.17,0.20$ and $0.40 \mathrm{mM}$ for $\mathbf{1}, \mathbf{2}$ and $\mathbf{3}$ respectively. Cell viability studies demonstrated that 1-3 probes are essentially non-toxic at concentrations $10-50 \mu \mathrm{M}$ and are well suited for in vivo studies. Finally, probe 1 was used for the detection on intracellular $\mathrm{HS}^{-}$anion in HeLa cells by means of confocal microscopy.
\end{abstract}

\section{Introduction}

Hydrogen sulfide $\left(\mathrm{H}_{2} \mathrm{~S}\right)$, along with $\mathrm{CO}$ and $\mathrm{NO}$, has been recognized as one of the three known endogenous gasotransmitters involved in many physiological processes of biological systems, ${ }^{[1]}$ such as cardiovascular, central nervous, respiratory, gastrointestinal and endocrine systems. Previously, NO has been successfully detected with suitable fluorophores for their fast and real-time determination in cells. ${ }^{[2]}$ For quite a long time, it was difficult to accurately and selectively detect $\mathrm{H}_{2} \mathrm{~S}$ without interruption by other reactive sulfur species, such as thiols, sulfenic acids and sulfites. $\mathrm{H}_{2} \mathrm{~S}$ may interact with downstream proteins by post-translational cysteine sulfhydration ${ }^{[3]}$ and binding to iron centers, ${ }^{[4]}$ which regulates various physiological processes including ischemia reperfusion injury ${ }^{[5]}$ vasodilation, ${ }^{[6]}$ apoptosis, ${ }^{[7]}$ angiogenesis, ${ }^{[8]}$ neuromodulation, ${ }^{[9]}$ inflammation ${ }^{[10]}$ and insulin signaling. ${ }^{[11]}$ Hydrogen sulfide's exact mechanisms of action are still under active investigation. Some chemical and biochemical catabolic reactions of $\mathrm{H}_{2} \mathrm{~S}$ have been reported. For example, $\mathrm{H}_{2} \mathrm{~S}$ can react readily with methemoglobin to form sulfhemoglobin, which act as the metabolic sink for $\mathrm{H}_{2} \mathrm{~S}$. As a potential reductant, $\mathrm{H}_{2} \mathrm{~S}$ is likely to be consumed by endogenous oxidant species such as hydrogen peroxide, superoxide, peroxynitrite, etc. This process is potentially significant because it provides a possible mechanism by which $\mathrm{H}_{2} \mathrm{~S}$ changes the functions of a wide range of cellular proteins and enzymes. However, abnormal levels of $\mathrm{H}_{2} \mathrm{~S}$ are associated with various diseases such as Alzheimer ${ }^{[12]}$ and Down syndrome. ${ }^{[13]} \mathrm{H}_{2} \mathrm{~S}$ is highly diffusible and reactive, so it is difficult to follow. Colorimetric, ${ }^{[14]}$ electrochemical, ${ }^{[15]}$ and chromatographic assays ${ }^{[16]}$ are available to measure $\mathrm{H}_{2} \mathrm{~S}$ in blood plasma and homogenized tissues, but they often require sample processing and do not provide much spatial and temporal information on $\mathrm{H}_{2} \mathrm{~S}$ concentrations and distribution in living cells and organisms.

By contrast, fluorescence imaging provides a tractive technique for biomolecules studding in living cells. As known, $\mathrm{H}_{2} \mathrm{~S}$ is a reductant as well as nucleophilic specie, which can specially react with some fluorogenic signaling subunits containing selected functional groups. Recently, several research groups have made great efforts toward the preparation of fluorogenic probes for the detection of hydrogen sulfide in blood and in cells. ${ }^{[17]}$ These probes are constructed bearing in mind the reactivity of the $\mathrm{HS}^{-}$anion. In particular, reduction, hydrolysis, nucleophilic additions and demetallation processes has been used as triggers for obtaining a fluorescent response for this anion. 
For instance, very recently, several examples of non-emissive $\mathrm{Cu}(\mathrm{II})$ complexes were used for the fluorogenic recognition of hydrogen sulfide. ${ }^{[18]}$ This anion is able to induce demetallation with the subsequent regeneration of fluorescent receptors. Michael-type additions ${ }^{[19]}$ and hydrolysis of disulfide bonds ${ }^{[20]}$ and 2,4-dinitropneylethers ${ }^{[21]}$ has also been extensively used in the development of fluorescent probes for hydrogen sulfide. However, probably, the type of reactions most used for the design of fluorogenic probes for hydrogen sulfide are reductions. In this context reductions of nitro, hydroxylamine and azide functional groups hy hydrogen sulfide have been selected due to their short reaction times, high yields and because usually can be carried out in water or in mixed aqueous environments. ${ }^{[22]}$ Among these reactions, the azide-amine reductions are perhaps the most used and several examples of probes based on this reaction have been developed. At this respect, in a pioneering work, Chang and co-workers prepared two weakly emissive rhodamine derivatives bearing azide moieties that yielded the correspondent fluorescent amines upon addition of $\mathrm{HS}^{-}$anion. ${ }^{[22 \mathrm{a}]}$ The authors also demonstrated that both probes are able to detect intracellular HS- anions in HEK293T cells using confocal microscopy. Wang and co-workers used a similar approach and prepared a dansyl sulfonylazide derivative that yielded a highly emissive dansyl sulfonamide upon reaction with $\mathrm{HS}^{-}{ }^{[22 \mathrm{~b}]}$ Cho and co-workers extended the fluorescent recognition of $\mathrm{HS}^{-}$anion to the use of two-photon probes. ${ }^{[22 \mathrm{c}]}$ Authors prepared a 7-(benzo[d]thiazol-2-yl)-9,9-(2methoxyethoxy)ethyl-9H-fluorene functionalized with an azide moiety. This probe has been used for the detection of HS $^{-}$ in vitro, in HeLa cells and in a rat hippocampal slice at a depth of 90-190 $\mu \mathrm{m}$ by using two-photon microscopy. A reduction reaction coupled with an intramolecular substitution was used by Han and co-workers for the preparation of a highly selective $\mathrm{HS}^{-}$fluorescent probe. ${ }^{[22 \mathrm{~d}]}$ In particular, 7-o-2'-(azidomethyl)benzoyl-4-methylcoumarin was prepared and the reduction of the azide to amine (induced by $\mathrm{HS}^{-}$) triggered the generation of fluorescent 7-hydroxy-4methylcoumarin fragment. Finally, also fluorescent proteins were recently modified with azide moieties and used for the fluorogenic detection of $\mathrm{HS}^{-}$in HeLa cells. ${ }^{[22 \mathrm{e}]}$

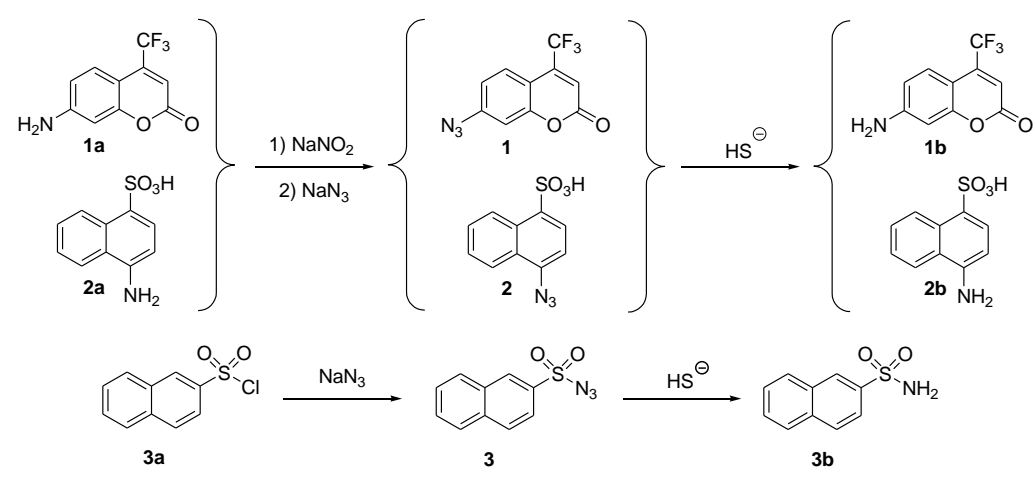

Scheme 1. Synthesis and chemical structure of probes 1-3.

Taking into account the above mentioned examples, and bearing in mind our interest in the preparation of chemodosimeters for the chromo-fluorogenic detection of anions with environmental or biological significance, ${ }^{[23]}$ here we present the synthesis, characterization and sensing features of three new molecular probes (1-3) for $\mathrm{HS}^{-}$detection. Probes $\mathbf{1}$ and $\mathbf{2}$ are azide derivatives of coumarin and naphthalene fluorophores whereas $\mathbf{3}$ is 2-sulfonylazidonaphthalene. The three probes are nearly non-fluorescent in aqueous environments and, upon addition of $\mathrm{HS}^{-}$anion, an emission was developed. The selectivity of the three probes is remarkable and other anions, bio-thiols and oxidants are unable to induce emission changes in 1-3. The probes showed remarkable limits of detection in the 0.1-0.4 $\mu \mathrm{M}$ range and can be used for the fluorescence detection of both exogenous and endogenous $\mathrm{HS}^{-}$in cells.

\section{Results and Discussion}

The fluorogenic probes: Three fluorogenic probes, 1, $\mathbf{2}$ and $\mathbf{3}$ have been prepared by conventional synthetic procedures (see Scheme 1). Probes $\mathbf{1}$ and $\mathbf{2}$ were obtained through an aromatic nucleophilic substitution from 7-amino-4(trifluoromethyl)coumarin (1a) and 4-amino-1-naphthalenesulfonic acid (1b) respectively. In a first step, 1a and 2a were reacted with sodium nitrite in acidic media yielding the corresponding diazonium salts. These salts were not isolated and were converted to $\mathbf{1}$ and $\mathbf{2}$ by reaction with sodium azide. Probe $\mathbf{3}$ was easily obtained by direct reaction of 2 naphthalenesulfonyl chloride (3a) with sodium azide. The final probes were characterized by ${ }^{1} \mathrm{H},{ }^{13} \mathrm{C}-\mathrm{NMR}$ and $\mathrm{HRMS}$ (see experimental section for details). ${ }^{1} \mathrm{H}-\mathrm{NMR}$ spectra of probe $\mathbf{1}$ is characterized by the presence of one singlet centered at $7.00 \mathrm{ppm}$ ascribed to the ethylene proton neighboring to the carbonyl group of the lactonic ring. Also, one characteristic signal is the sharp doublet centered at $7.34 \mathrm{ppm}$ attributed to the proton located between the azide moiety and the oxygen atom of the lactone ring. Moreover, the IR spectra of $\mathbf{1}$ showed the typical strong band of the azide stretching at $2117 \mathrm{~cm}^{-}$ ${ }^{1}$. Dealing with probe $\mathbf{2}$, the most characteristic signals in the ${ }^{1} \mathrm{H}-\mathrm{NMR}$ spectra are two doublets centered at 8.03 and 8.85 ppm that are ascribed to the protons located near the azide and sulfonic acid moieties respectively. Also for probe 2 the stretching band of the azide moiety is observed at $2128 \mathrm{~cm}^{-1}$. Finally, the more characteristic signals of probe $\mathbf{3}$ are a singlet centered at $8.55 \mathrm{ppm}$ and two doublets centered at 7.97 and $7.90 \mathrm{ppm}$ that were ascribed to the aromatic ring containing the sulfonyl azide moiety (stretching at $2131 \mathrm{~cm}^{-1}$ ). 
Hydrogen sulfide recognition: The three synthesized probes are composed by a fluorophore directly linked with an azide moiety (probes $\mathbf{1}$ and $\mathbf{2}$ ) or functionalized with a sulfonyl azide functional group (probe $\mathbf{3}$ ). It is well documented the ability of hydrogen sulfide to reduce azide groups to amines. ${ }^{[24]}$ In addition when azides are coupled with a fluorophore, the difference in the electronic properties of this moiety and the amino group is expected to trigger the emission properties of the fluorophore with the subsequent recognition of hydrogen sulfide anion. In fact this simple sensing mechanism has been used, very recently, in the preparation of selective and sensitive probes for $\mathrm{HS}^{-}$anion in water and in cellular media. ${ }^{[22]}$ For these probes the selectivity observed is high due to the fact that reduction of an azide to the correspondent amine by hydrogen sulfide is faster than that observed when GSH and Cys are used. This is a consequence of the small size and lower $\mathrm{pK}_{\mathrm{a}}$ (6.9) of the hydrogen sulfide when compared to GSH and Cys ( $\mathrm{pK}_{\mathrm{a}}$ values about 8.5). ${ }^{[25]}$

In a first step, the sensing features of the three synthesized probes 1-3 was evaluated in the presence of selected anions $\left(\mathrm{F}^{-}\right.$, $\mathrm{Cl}^{-}, \mathrm{Br}^{-}, \mathrm{I}^{-}, \mathrm{N}_{3}^{-}, \mathrm{OH}^{-}, \mathrm{CN}^{-}, \mathrm{SCN}^{-}, \mathrm{AcO}^{-}$, citrate, $\mathrm{NO}_{3}^{-}, \mathrm{HCO}_{3}^{-}, \mathrm{H}_{2} \mathrm{PO}_{4}^{-}, \mathrm{SO}_{4}{ }^{2-}$ and $\left.\mathrm{HS}^{-}\right)$, reducing agents $\left(\mathrm{SO}_{3}{ }^{2-}\right.$ and $\left.\mathrm{S}_{2} \mathrm{O}_{3}{ }^{2-}\right)$, oxidants $\left(\mathrm{H}_{2} \mathrm{O}_{2}\right)$ and thiol-containing biomolecules (lipoic acid, Cys, MeCys, Hcy and GSH) in HEPES (10 mM, pH 7.4)DMSO 99:1 v/v. Probes $\mathbf{1}$ and $\mathbf{3}$ are nearly non-fluorescent whereas $\mathbf{2}$ showed a very weak emission band centered at 420. As a general trend, Figure 1 shows how addition of $\mathrm{HS}^{-}$to 1-3 induced a significant fluorescent "turn-on" response, whereas addition of the other anions, oxidants and biothiols induced negligible changes in the emission.

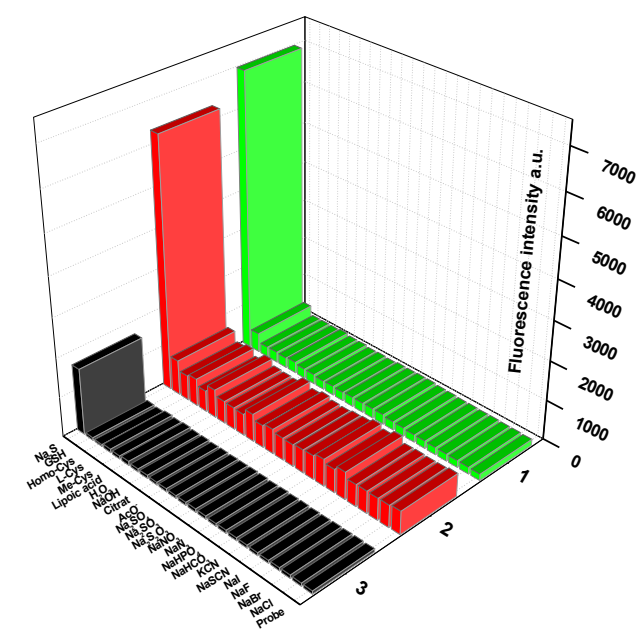

Figure 1. Emission intensity of probes (5 $\mu \mathrm{M}) 1$ (at $496 \mathrm{~nm}$ upon excitation at $420 \mathrm{~nm}$ ), 2 (at $420 \mathrm{~nm}$ upon excitation at $350 \mathrm{~nm}$ ) and 3 (at $350 \mathrm{~nm}$ upon excitation at $295 \mathrm{~nm}$ ) in HEPES (10 mM, pH 7.4)-DMSO 99:1 v/v solutions upon addition of 10 equivalents of anions, bio-thiols, reducing agents and oxidants (after 50 minutes of the addition).

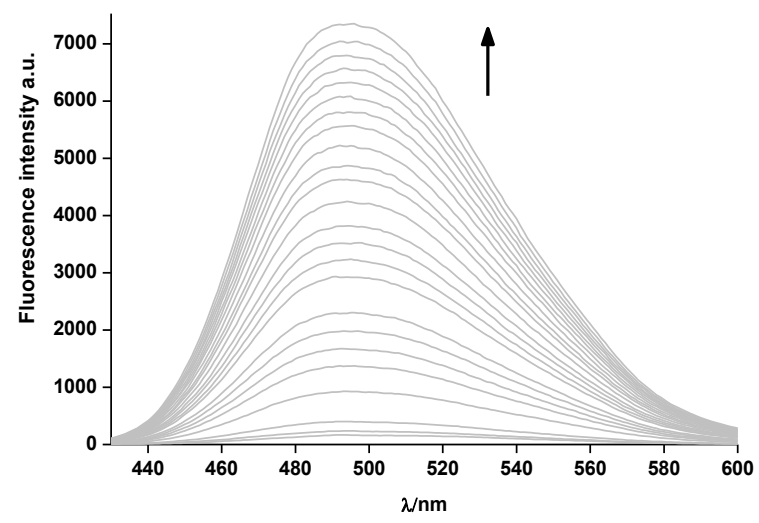

Figure 2. Fluorescene enhancement of probe $1(5 \mu \mathrm{M})$ in HEPES (10 mM, pH 7.4)-DMSO 99:1 v/v solution upon addition of increasing quantities of $\mathrm{HS}^{-}$anion (from 0 to 10 equivalents) after 50 minutes of the addition (excitation at $420 \mathrm{~nm}$ ).

More in detail, addition of 10 equivalents of HS- anion to HEPES (10 mM, pH 7.4)-DMSO 99:1 v/v solution of probe 1 (5 $\mu \mathrm{M})$ induced the appearance of an emission band centered at $496 \mathrm{~nm}\left(\lambda_{\mathrm{ex}}=420 \mathrm{~nm}\right)$ that reached their maximum intensity after 50 minutes upon addition of 10 equivalents of $\mathrm{HS}^{-}$. The intensity enhancement for probe $\mathbf{1}$ is ca. 50 -fold. Nearly the same results were obtained when probe 2 is used. In particular, HEPES (10 mM, pH 7.4)-DMSO 99:1 v/v solution of 
probe $2(5 \mu \mathrm{M})$ showed a very weak emission band centered at $420 \mathrm{~nm}$ upon excitation at $350 \mathrm{~nm}$. Again, of all the anions, oxidants and biothiols tested, only addition of $\mathrm{HS}^{-}$anion induced a remarkable 11-fold enhancement (after 50 minutes of the addition) of the emission band. Finally, HEPES (10 mM, pH 7.4)-DMSO 99:1 v/v solution of probe 3 (5 $\mu \mathrm{M})$ are non-emissive but the typical broad unstructured band of the naphthalene fluorophore at ca. $350 \mathrm{~nm}\left(\lambda_{\mathrm{ex}}=295\right.$ $\mathrm{nm}$ ) emerged upon addition of $\mathrm{HS}^{-}$anion (20-fold enhancement after 50 minutes of the addition).

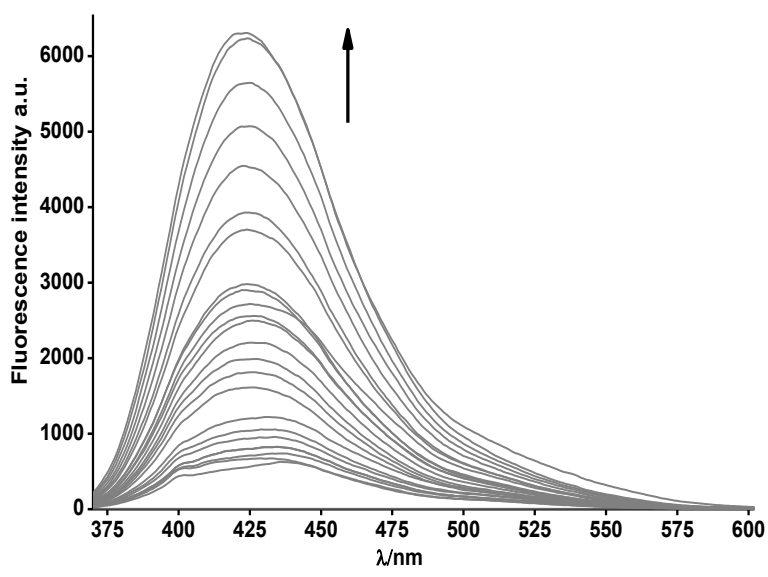

Figure 3. Fluorescene enhancement of probe $2(5 \mu M)$ in HEPES (10 mM, pH 7.4)-DMSO 99:1 v/v solution upon addition of increasing quantities of $\mathrm{HS}^{-}$anion (from 0 to 10 equivalents) after 50 minutes of the addition (excitation at $350 \mathrm{~nm}$ ).

Once assessed the selectivity of the three probes toward $\mathrm{HS}^{-}$, in a second step, sensitivity studies were carried out. Addition of increasing quantities of HS ${ }^{-}$anion to HEPES (10 mM, pH 7.4)-DMSO 99:1 v/v solution of probe 1 (5 $\mu$ M) induced a progressive enhancement in the emission centered at $496 \mathrm{~nm}$ (see Figure 2). From the titration profile a limit of detection (LOD) of $0.17 \mu \mathrm{M}$ for $\mathrm{HS}^{-}$was determined. Similar titration experiments with 2 allowed to determine a LOD of $0.20 \mu \mathrm{M}$ (see Figure 3), whereas LOD calculated for 3 was $0.40 \mu \mathrm{M}$. The low limits of detection determined for the three probes suggested that these could be used to detect $\mathrm{HS}^{-}$in cells as the LOD are below the hydrogen sulfide concentration required to elicit physiological responses $(10-1000 \mu \mathrm{M}){ }^{[26]}$

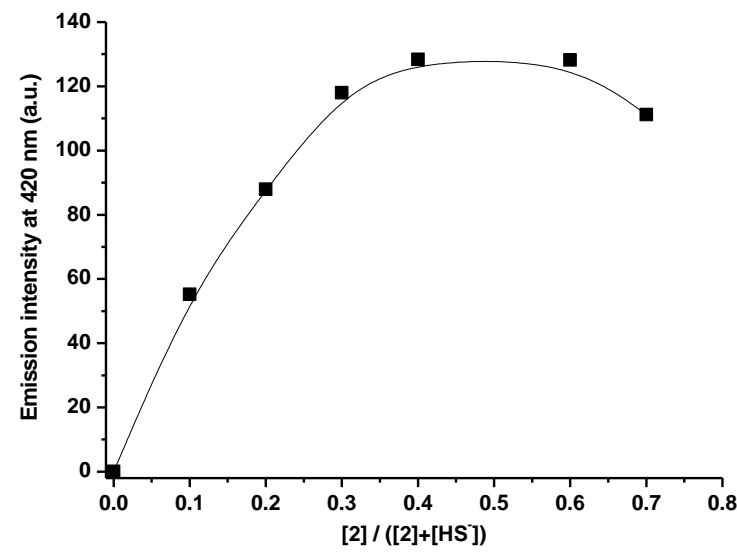

Figure 4. Job's plot for the reaction between probe 2 and $\mathrm{HS}^{-}$anion determined by fluorescence (emission at 420 nm registered after 50 minutes of the addition, excitation at $350 \mathrm{~nm})$ in HEPES (10 mM, pH 7.4)-DMSO 99:1 v/v solution and with [2]+[HS $]=10 \mu \mathrm{M}$.

The selective emission enhancements observed for 1-3 probes was ascribed to an $\mathrm{HS}^{-}$induced reduction of the azide moieties presented in the chemical structure of the three dosimeters (see Scheme 1). The stoichiometry of the reaction between probes 1-3 and $\mathrm{HS}^{-}$anion is 1:1, confirmed by the corresponding Job's plots. As an example, Figure 4 showed the Job's plot obtained for probe $\mathbf{2}$ and $\mathrm{HS}^{-}$anion. These hydrolysis reactions yielded the correspondent highly fluorescent amines $\mathbf{1 b}$ and $\mathbf{2 b}$ (in the case of probes $\mathbf{1}$ and $\mathbf{2}$ ) and sulfonamide $\mathbf{3 b}$ (in the case of probe $\mathbf{3}$ ). The hydrogen sulfideinduced azide-amine reduction as a mechanism of the fluorescence response observed has been corroborated by the isolation of $\mathbf{1 b}, \mathbf{2} \mathbf{b}$ and $\mathbf{3} \mathbf{b}$ after the reaction of the probes with $\mathrm{Na}_{2} \mathrm{~S}$. In a typical experiment, probes $\mathbf{1 - 3}$ were dissolved in ethanol and then an excess of $\mathrm{Na}_{2} \mathrm{~S}$ was added. The mixtures were stirred at room temperature for $1 \mathrm{~h}$. Then the ethanol was eliminated in a rotary evaporator and the crudes obtained were purified by silica column chromatography. The ${ }^{1} \mathrm{H}$ and 
${ }^{13} \mathrm{C}$ of the final products were coincident with that of $\mathbf{1 b}, \mathbf{2} \mathbf{b}$ and $\mathbf{3 b}$ amines. Besides, the hydrogen sulfide-induced azideamine reduction was corroborated by ${ }^{1} \mathrm{H}-\mathrm{NMR}$ titration measurements. At this respect, DMSO-D6 solutions of probe $\mathbf{1}$ showed the protons of the aromatic ring containing the azide moiety centered at $7.71(\mathrm{Ha}), 7.34(\mathrm{Hc})$ and $7.23(\mathrm{Hb})(\mathrm{see}$ Figure 5 for proton assignation). Addition of increasing quantities of $\mathrm{HS}^{-}$anion induced a progressive upfield shift of the three protons (see also Figure 5) that would be clearly ascribed to the reduction of the electron withdrawing azide group to an electron donor amine moiety.

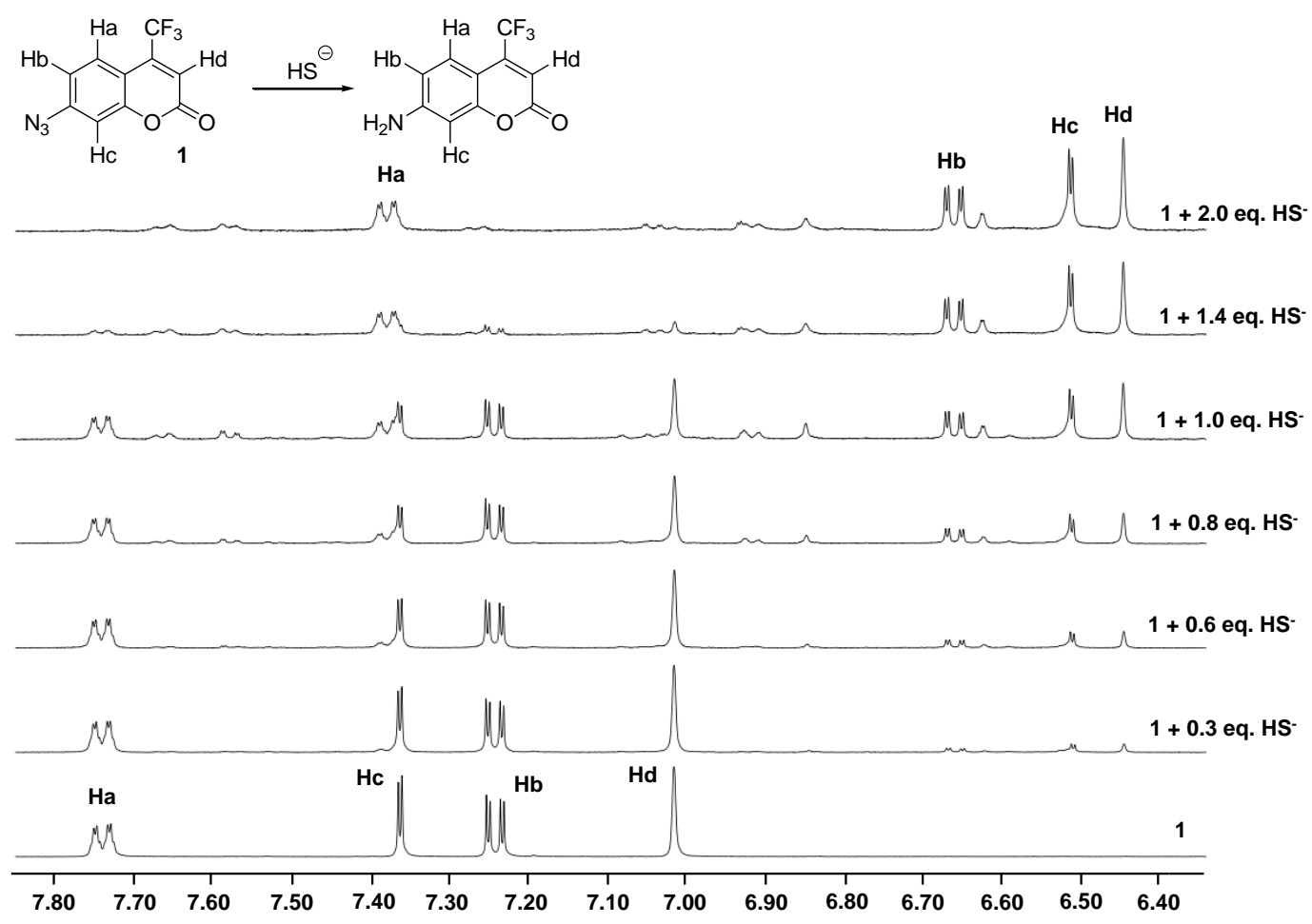

Figure 5. ${ }^{1} \mathrm{H}$-NMR spectra of probe 1 in DMSO-D6 alone and in the presence of 0.3, 0.6, 0.8, 1, 1.4 and 2 equivalents of $\mathrm{HS}^{-}$anion.

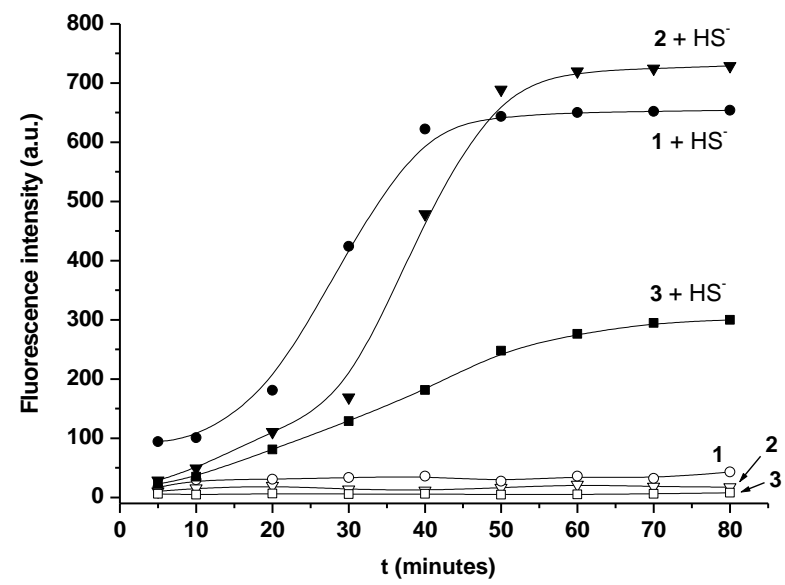

Figure 6. Emission intensity changes of the three probes $(5 \mu M)$ at different times in the absence and in the presence of $\mathrm{HS}^{-}$anion (10 equivalents). Emission at 496, 420 and $350 \mathrm{~nm}$ for probe $1(\bullet), 2(\nabla)$ and $3(\square)$ respectively in prescence of 10 equivalents of $\mathrm{HS}^{-}$ anion. The picture also show the changes of probes in the absence of $\mathrm{HS}^{-}(1(0), 2(\nabla)$ and $3(\square))$.

The time dependent fluorescence enhancement of the three probes $(5 \mu \mathrm{M})$ upon addition of $\mathrm{HS}^{-}$anion $(50 \mu \mathrm{M})$ was studied. The obtained results are depicted in Figure 6. As could be seen, for the three probes, the emission intensity increased gradually with time until ca. 50 minutes. At this time nearly constant emission intensity was observed indicative of the complete reduction of the azide moiety. 


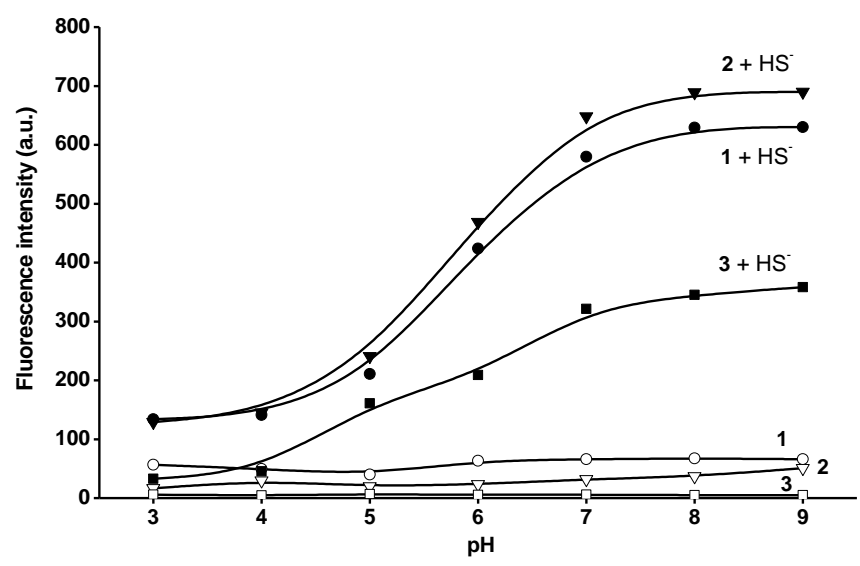

Figure 7. Emission intensity changes of the three probes $(5 \mu M)$ at different $\mathrm{pH}$ values in the absence and in the presence of $\mathrm{HS}$ anion (10 equivalents) after 50 minutes of the addition. Emission at 496, 420 and $350 \mathrm{~nm}$ for probe $1(\bullet), 2(\nabla)$ and $3(\square)$ respectively in the prescence of 10 equivalents of $\mathrm{HS}^{-}$anion. The picture also show the changes of probes in the absence of $\mathrm{HS}^{-}(1$ (0), $2(\nabla)$ and $3(\square)$.

Also, the emission behavior of the three probes in the absence and in the presence of $\mathrm{HS}^{-}$anion at different $\mathrm{pH}$ was also studied. The weak (for 2) or negligible (for $\mathbf{1}$ and 3) emission remained unchanged in the 3-9 $\mathrm{pH}$ range. In the presence of $\mathrm{HS}^{-}$anion $(50 \mu \mathrm{M})$, the emission intensity of the probes $(5 \mu \mathrm{M})$ did not change in the 3-5 $\mathrm{pH}$ range, whereas the maximum intensity was observed at $\mathrm{pH}$ from 7 to 9 (see Figure 7). This is an expected result bearing in mind the fact that below $\mathrm{pH} 7.0$ hydrogen sulfide is in the $\mathrm{H}_{2} \mathrm{~S}$ form (the $\mathrm{pK}_{\mathrm{a}}$ is 6.9 ) which is unable to promote the azide-amine reduction.

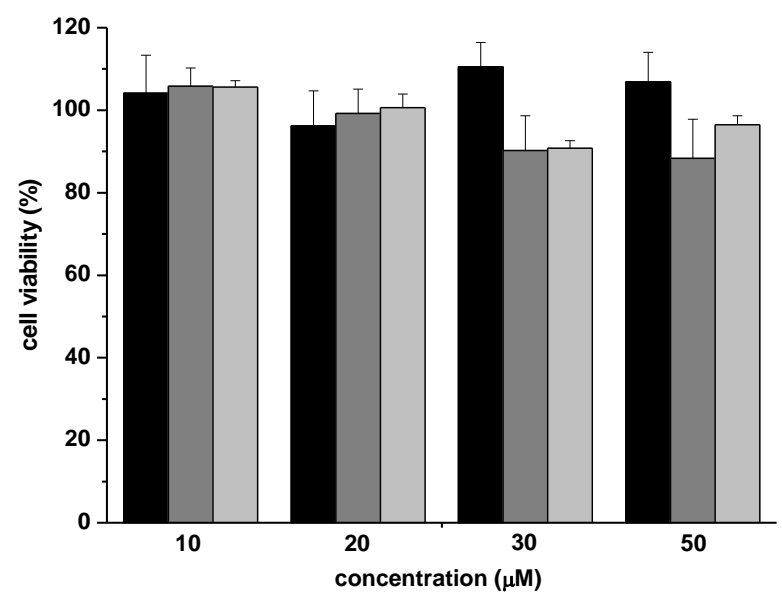

Figure 8. Cell viability assays. HeLa cells were treated with probes 1 (black), 2 (grey) and 3 (light grey) at concentrations between 10 and $50 \mu M$ for $24 h$. Then cell viability was quantified by means of WST-1 assay.

Cell viability studies: The selective and sensitive emission enhancements observed for the three probes in the presence of $\mathrm{HS}^{-}$anion and the absence of any modulation of the fluorescence upon addition of GSH, Cys and Hcy strongly suggest that 1-3 can be used for HS $^{-}$detection and imaging in living cells. Based on these observations, the cytotoxicity of 1-3 was first evaluated. For this purpose HeLa cells were treated with the three probes at different concentrations (10, 20, 30 and $50 \mu \mathrm{M}$ ) over a 24-hour period and cell viability was determined by a WST-1 assay. The obtained results are shown in Figure 8. As seen, the three probes are essentially non-toxic in the range of concentrations tested.

Detection of HS $^{-}$in HeLa cells: Once assessed the biocompatibility of the prepared probes, and with the aim to test the probes in highly competitive environments, we prospectively used probe $\mathbf{1}$ for the fluorescence imaging of sulfide in living cells. 

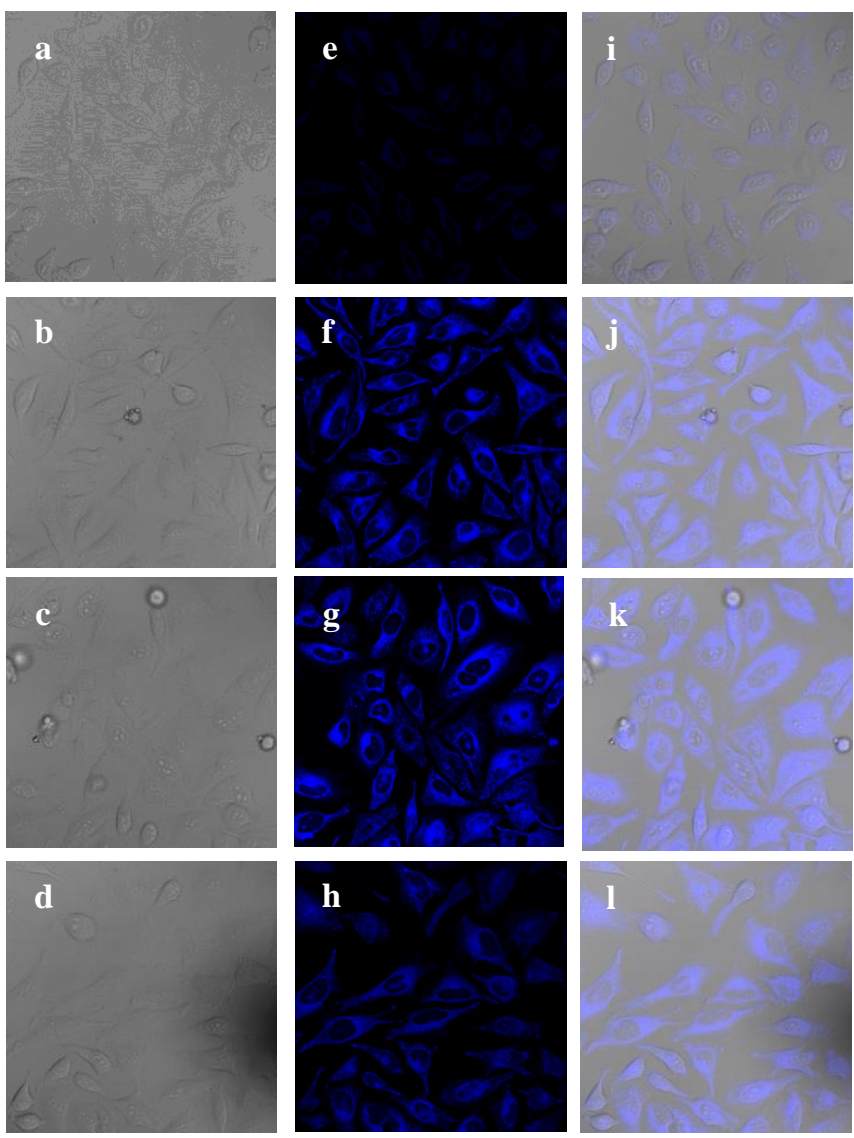

Figure 9. Confocal microscopy images of $\mathrm{H}_{2} \mathrm{~S}$ detection in HeLa cells using probe 1 (a-d). Bright field images of the cells (e,i) HeLa cells incubated with probe 1 for 30 minutes at $37^{\circ} \mathrm{C}$, $(f, j) \mathrm{HeLa}$ cells incubated with probe 1 for 30 minutes at $37^{\circ} \mathrm{C}$ and 30 minutes incubated with $100 \mu \mathrm{M}$ NaHS, (g,k) with $200 \mu \mathrm{M}$ NaHS and (h,l) $500 \mu \mathrm{M}$ NaHS. The excitation and emission wavelength were 420$440 \mathrm{~nm}$ and 490-530 $\mathrm{nm}$.

In a typical experiment, HeLa cells were incubated in DMEM supplemented with $10 \%$ fetal bovine serum. To conduct fluorescence microscopy studies, HeLa cells were seeded in $24 \mathrm{~mm}$ glass coverslips in 6-well plates and were allowed to settle for $24 \mathrm{~h}$. Cells were treated with probe 1, in PBS-DMSO 99:1 v/v, at final concentrations of $50 \mu \mathrm{M}$. After 30 minutes, the medium was removed and solutions of different concentrations of NaHS in PBS were added (0, 100, 200 and $500 \mu \mathrm{M})$ and cells were incubated for another 30-minute period. The result is shown in Figure 9. The control experiment (HeLa cells without dosimeters) and the cells incubated with $\mathbf{1}$ showed no fluorescence, whereas a marked enhancement in intracellular emission was observed in the $\mathrm{HS}^{-}$-treated cells. The emission enhancement observed is clearly dependent of the amount of NaHS added. The enhancement in the intracellular fluorescence intensity with 1 was quantified by a standard image analysis and the results are shown in Figure 10. All, the above mentioned facts clearly indicated the possible use of probe $\mathbf{1}$ to detect hydrogen sulfide in complex media.

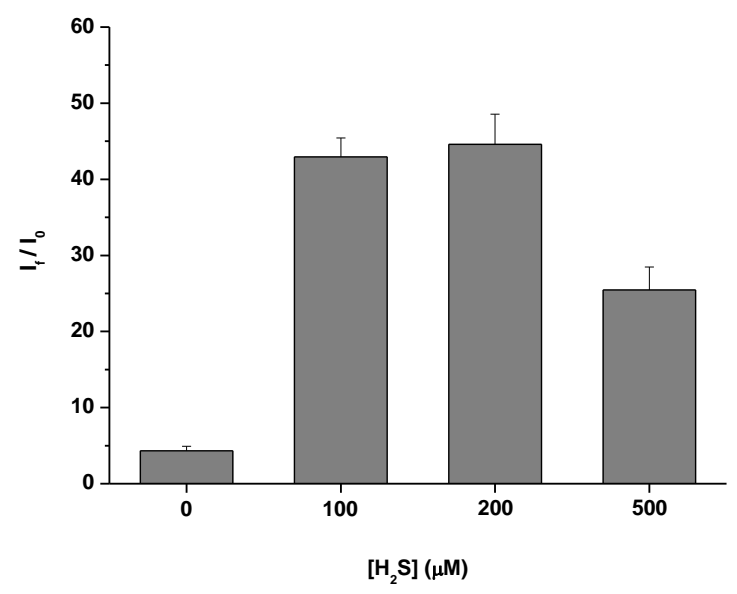

Figure 10. Average $I_{f} / I_{0}$ intensity ratios of probe $1(50 \mu M)$ in HeLa cells after addition of 0, 100, 200 and $500 \mu M$ of $\mathrm{Na}_{2} \mathrm{~S}$ in PBS buffer. Representative fluorescence images from replicate experiments $(n=3)$ are shown. Error bars are $(S D)$. 


\section{Conclusions}

In summary, we have synthesized three chemodosimeters (1-3) as fluorescence turn-on $\mathrm{H}_{2} \mathrm{~S}$ probes. HEPES (10 mM, pH 7.4)-DMSO 99:1 v/v solutions of the three probes are practically non-fluorescent and only the addition of $\mathrm{HS}^{-}$anion induced remarkable emission enhancements. The emission enhancements observed are due to a selective sulfide-induced reduction of azide and sulfonylazide to amine (yielding $\mathbf{1 b}$ and $\mathbf{2 b}$ ) and sulfonamide (yielding $\mathbf{3 b}$ ) moieties. Probes 1-3 can selectively and sensitively detect $\mathrm{HS}^{-}$anion in water over other anions, biothiols and common oxidants. The titration profiles obtained upon addition of increasing quantities of $\mathrm{HS}^{-}$anion to aqueous solutions of the three dosimeters allowed us to determine limits of detection of $0.17,0.20$ and $0.40 \mu \mathrm{M}$ for $\mathbf{1 , 2}$ and $\mathbf{3}$, respectively. Besides the three probes showed remarkably low sensitivities below the hydrogen sulfide concentration required to elicit physiological responses (10-1000 $\mu \mathrm{M})$. Cell viability assays showed that 1-3 probes are essentially non-toxic in the 10-50 $\mu \mathrm{M}$ range. Moreover, real-time fluorescence imaging measurements have confirmed that probe $\mathbf{1}$ can be used to detect intracellular $\mathrm{HS}^{-}$at micromolar concentrations.

\section{Experimental Section}

Materials and methods: UV-visible spectra were recorded with a JASCO V-650 Spectrophotometer. Fluorescence measurements were carried out in a JASCO FP-8500 Spectrophotometer. 1H and 13C-NMR spectra were acquired in a BRUKER ADVANCE III (400 MHZ), where mass spectra were carried out in a TRIPLETOF T5600 (ABSciex, USA) spectrometer, IR in BRUKER TENSOR 27.

The chemicals 7-amino-4-(trifluoromethyl)coumarin, 4-amino-1-naphthalenesulfonic acid, 2-naphthalenesulfonyl chloride, sodium bicarbonate, sodium azide and sodium nitrite were purchased from Sigma-Aldrich. Hydrochloric acid $(37 \%)$ and sulfuric acid $(95 \%)$ were purchased from Scharlau (Barcelona, Spain).

Ssynthesis of probes 1 and 2: 7-Amino-4-(trifluoromethyl)coumarin (1a) or 4-amino-1-naphthalenesulfonic acid (1b) $(0.22 \mathrm{mmol})$ were dissolved in $3.6 \mathrm{M} \mathrm{H}_{2} \mathrm{SO}_{4}(500 \mu \mathrm{L})$ and then cooled to $2{ }^{\circ} \mathrm{C}$ with an ice bath. After that, an aqueous solution of $\mathrm{NaNO}_{2}(0.66 \mathrm{M}, 1 \mathrm{~mL}, 0.66 \mathrm{mmol})$ was added dropwise over 10 minutes period. Then, $\mathrm{NaN}_{3}$ aqueous solution $(1.2 \mathrm{~mL}, 1.32 \mathrm{mmol})$ was added dropwise during 10 minutes and the reaction crude was stirred at $2{ }^{\circ} \mathrm{C}$ for an additional 40 minutes. Finally, the crude reaction was quenched by addition of concentrated $\mathrm{NH}_{4} \mathrm{OH}(0.5 \mathrm{~mL})$ and the final products $(\mathbf{1}$ and 2) precipitated as white solids. The final probes were crystalized from ethanol (1: $53.6 \mathrm{mg}, 0.21 \mathrm{mmol}, 95 \%$ yield; 2 : $30.2 \mathrm{mg}, 0.12 \mathrm{mmol}, 55 \%$ yield). 1: ${ }^{1} \mathrm{H}$ NMR (400 MHz, DMSO) $\delta 7.71(\mathrm{dd}, J=8.7, J=1.0,1 \mathrm{H}), 7.34(\mathrm{~d}, J=2.3 \mathrm{~Hz}$, $1 \mathrm{H}), 7.23(\mathrm{dd}, J=8.7,2.3 \mathrm{~Hz}, 1 \mathrm{H}), 7.00(\mathrm{br} \mathrm{s}, 1 \mathrm{H}) .{ }^{13} \mathrm{C}$ NMR (101 MHz, DMSO) $\delta 158.3,155.0,144.7,126.3,116.6$, 115.7, 113.0, 112.9, 110.1, 107.6. HRMS-EI $m / z$ : calcd for $\mathrm{C}_{10} \mathrm{H}_{4} \mathrm{~F}_{3} \mathrm{~N}_{3} \mathrm{O}_{2}$ 255.0256; found: $256.0123\left(\mathrm{M}+\mathrm{H}^{+}\right)$. 2: ${ }^{1} \mathrm{H} \mathrm{NMR}$ (400 MHz, DMSO) $\delta 8.85(\mathrm{dd}, J=7.8,1.5 \mathrm{~Hz}, 1 \mathrm{H}), 8.07-7.94(\mathrm{~m}, 2 \mathrm{H}), 7.64-7.49(\mathrm{~m}, 2 \mathrm{H}), 7.37(\mathrm{~d}, J=7.8 \mathrm{~Hz}, 1 \mathrm{H})$. ${ }^{13} \mathrm{C}$ NMR (101 MHz, DMSO) $\delta$ 158.3, 155.0, 144.7, 126.3, 116.6, 115.8, 113.0, 110.1, 107.8. HRMS-EI $\mathrm{m} / z$ : calcd for $\mathrm{C}_{10} \mathrm{H}_{7} \mathrm{~N}_{3} \mathrm{O}_{3} \mathrm{~S} 249.0208$; found: $250.0118\left(\mathrm{M}+\mathrm{H}^{+}\right)$.

Synthesis of probe 3: 2-naphthalenesulfonyl chloride (3a, $1 \mathrm{~g}, 4.4 \mathrm{mmol})$ was dissolved in acetone $(20 \mathrm{~mL})$ and then an aqueous solution of $\mathrm{NaN}_{3}(860 \mathrm{mg}, 13.2 \mathrm{mmol}, 4 \mathrm{~mL})$ was added dropwise during 15 minutes. Afterwards, the crude reaction was stirred at room temperature for 24 hours. Then, acetone was eliminated using a reotary evaporator and the formed solid washed with water and with an aqueous solution of $\mathrm{Na}_{2} \mathrm{~S}_{2} \mathrm{O}_{5}\left(670 \mathrm{mg}, 2.9 \mathrm{mmol}, 65 \%\right.$ yield). ${ }^{1} \mathrm{H}$ NMR (400 $\left.\mathrm{MHz}, \mathrm{CDCl}_{3}\right) \delta 8.55(\mathrm{~d}, J=1.5 \mathrm{~Hz}, 1 \mathrm{H}), 8.04(\mathrm{t}, J=9.0 \mathrm{~Hz}, 2 \mathrm{H}), 7.97(\mathrm{~d}, J=8.4 \mathrm{~Hz}, 1 \mathrm{H}), 7.90(\mathrm{dd}, J=8.7,2.0 \mathrm{~Hz}, 1 \mathrm{H})$, $7.76-7.64(\mathrm{~m}, 2 \mathrm{H}) .{ }^{13} \mathrm{C}$ NMR $\left(101 \mathrm{MHz}, \mathrm{CDCl}_{3}\right) \delta 135.8,135.4,132.1,130.4,130.1,129.71,128.3,122.0$. HRMS-EI $m / z$ : calcd for $\mathrm{C}_{10} \mathrm{H}_{7} \mathrm{~N}_{3} \mathrm{O}_{2} \mathrm{~S} 233.0259$; found: $234.0243\left(\mathrm{M}+\mathrm{H}^{+}\right)$.

Cell culture conditions: The HeLa human cervix adenocarcinoma cells were purchased from the German Resource Centre for Biological Materials (DSMZ) and were grown in DEM supplemented with $10 \%$ FBS. Cells were maintained at $37^{\circ} \mathrm{C}$ in an atmosphere of $5 \% \mathrm{CO}_{2}$ and $95 \%$ air ad underwent passage twice in a week.

WST-1 cell viability assays: Cells were cultured in sterile 96-well microtiter plates at a seeding density of $2.5 \times 10^{3}$ cells/well for HeLa and were allowed to settle for $24 \mathrm{~h}$. Probes 1, 2 and $\mathbf{3}$ were added to the cells at a final concentrations of 10, 20, 30 and $50 \mu \mathrm{M}$. After $23 \mathrm{~h}$, WST-1 ( $7 \mu \mathrm{L}$ of a $50 \mathrm{mg} / \mathrm{ml}$ solution) was added to each well. Cells were further incubated for $1 \mathrm{~h}$ (a total of $24 \mathrm{~h}$ of incubation was therefore studied). Then shaked thoroughly for 1 minute on a shaker and the absorbance was measured at $450 \mathrm{~nm}$ against a background control as blank using a microplate ELISA reader. The reference wavelength is $690 \mathrm{~nm}$.

Live confocal microscopy: Hela cells were seeded in $24 \mathrm{~mm}$ glass coverslips in 6-well microtiter plates at a seeding density of $10^{-5}$ cells/well. After 24 hours, cells were treated with probe 1 at a final concentration of $50 \mu \mathrm{M}$. After 30 minutes, the medium was removed to eliminate probe $\mathbf{1}$ and washed with PBS. Then a solution of $\mathrm{Na}_{2} \mathrm{~S}$ in PBS was added at a final concentrations of $0,100,200,500 \mu \mathrm{M}$ and cells were incubated during 30 minutes at $37{ }^{\circ} \mathrm{C}$. After that, slides 
were washed twice with PBS to remove traces of the probe. Then slides were visualized under a confocal.

Confocal microscopy studies were performed by Confocal Microscopy Service (CIPF). The images were acquired with a Leica TCS SP2 AOBS (Leica Microsystems Heidelberg GmbH, Mannheim, Germany) inverted laser scanning confocal microscope using oil objectives: 63X Plan-Apochromat-Lambda Blue 1.4 N.A. The excitation wavelength was $488 \mathrm{~nm}$ (argon laser). Two-dimensional pseudo colour images (255 colour levels) were gathered with a size of 1024 x 1024 pixels and Airy 1 pinhole diameter. All confocal images were acquired using the same settings and the distribution of fluorescence was analyzed using the Image J Software. Identical experiments were done three times to obtain reproducible results.

\section{Acknowledgements}

Financial support from the Spanish Government (Project MAT2012-38429-C04-01) and the Generalitat Valencia (Project PROMETEO/2009/016) is gratefully acknowledged. S.E. is grateful to the Generalitat Valenciana for his Santiago Grisolia fellow. C. T. also thanks the Ministerio de Ciencia e Innovación for her FPU grant. L.E.S.F. thanks the Carolina Foundation and UPNFM-Honduras for his doctoral grant.

\section{References}

[1] a) C. Szabo, Nat. Rev. Drug. Discov. 2007, 6, 917-935; b) S. Fiorucci, E. Antonelli, A. Mencarelli, S. Orlandi, B. Renga, G. Rizzo, E. Distrutti, V. Shah, A. Morelli, Hepatology 2005, 42, 539-548.

[2] a) L. E. McQuade, S. J. Lippard, Curr. Opin. Chem. Biol. 2010, 14, 43-49; b) E. W. Miller, C. J. Chang, Curr. Opin. Chem. Biol. 2007, 11, 620-625; c) N. Boens, V. Leen, W. Dehaen, Chem. Soc. Rev. 2012, 41, 1130-1172.

[3] A. K. Mustafa, M. M. Gadalla, N. Sen, S. Kim, W. Mu, S. K. Gazi, R. K. Barrow, G. Yang, R. Wang, S. H. Snyder, Sci. Signaling 2009 , 2, ra72.

[4] E. Blackstone, M. Morrison, M. B. Roth, Science 2005, 308, 518-519.

[5] J. W. Elrod, J. W. Calvert, J. Morrison, J. E. Doeller, D. W. Kraus, L. Tao, X. Jiao, R. Scalia, L. Kiss, C. Szabo, H. Kimura, C.-W. Chow, D. J. Lefer, Proc. Natl. Acad. Sci. U. S. A. 2007, 104, 15560-15565.

[6] G. Yang, L. Wu, B. Jiang, B. Yang, J. Qi, K. Cao, Q. Meng, A. K. Mustafa, W. Mu, S. Zhang, S. H. Snyder, R. Wang, Science 2008, 322, 587-590.

[7] G. Yang, L. Wu, R. Wang, FASEB J. 2006, 20, 553-555.

[8] A. Papapetropoulos, A. Pyriochou, Z. Altaany, G.Yang,A.Marazioti, Z. Zhou, M. G. Jeschke, L. K. Branski, D. N. Herndon, R. Wang, C. Szabó , Proc. Natl. Acad. Sci. U. S. A. 2009, 106, 21972-21977.

[9] K. Abe, H. Kimura, J. Neurosci. 1996, 16, 1066-1071.

[10] L. Li, M. Bhatia, Y. Z. Zhu, Y. C. Zhu, R. D. Ramnath, Z. J. Wang, F. B. Anuar, M. Whiteman, M. Salto-Tellez, P. K. Moore, FASEB J. 2005, 19, 1196-1198.

[11] W. Yang, G. D. Yang, X. M. Jia, L. Y. Wu, R. Wang, J. Physiol. 2005, 569, 519-531

[12] K. Eto, T. Asada, K. Arima, T. Makifuchi, H. Kimura, Biochem. Biophys. Res. Commun. 2002, 293, 1485-1488.

[13] P. Kamoun, M.-C. Belardinelli, A. Chabli, K. Lallouchi, B. Chadefaux-Vekemans, Am. J. Med. Genet. A 2003, 116A, $310-311$.

[14] R. R. Moest, Anal. Chem. 1975, 47, 1204-1205.

[15] A. V. Kroll, V. Smorchkov, A. Y. Nazarenko, Sensors Act. B: Chem. 1994, 21, 97-100.

[16] T. W. Mitchell, J. C. Savage, D. H. Gould, J. Appl. Toxicol. 1993, 13, 389-394.

[17] a) R. Martínez-Máñez, F. Sancenón, Chem. Rev. 2003, 103, 4419-4476; b) M. E. Moragues, R. Martínez-Máñez, F. Sancenón, Chem. Soc. Rev. 2011, 40, 2593-2643; c) L. E. Santos-Figueroa, M. E. Moragues, E. Climent, A. Agostini, R. Martínez-Máñez, F. Sancenón, Chem. Soc. Rev. 2013, 42, 3489-3613; d) C. Coll, A. Bernardos, R. Martínez-Máñez, F. Sancenón, Acc. Chem. Res. 2013, 46, 339-349.

[18] a) K. Sasakura, K. Hanaoka, N. Shibuya, Y. Mikami, Y. Kimura, T. Komatsu, T. Ueno, T. Terai, H. Kimura, T. Nagano, J. Am. Chem. Soc., 2011, 133, 18003-18005; b) L. E. Santos-Figueroa, C. de la Torre, S. El Sayed, F. Sancenón, R. Martínez-Máñez, A. M. Costero, S. Gil, M. Parra, Eur. J. Inorg. Chem. 2014, 41-45; c) M. -Q. Wang, K. Li, J. -T. Hou, M. -Y. Wu, Z. Huang, X. -Q. Yu, J. Org. Chem. 2012, 77, 8350-8354; d) C. Gao, X. Liu, X. Jin, J. Wu, Y. Xie, W. Liu, X. Yao, Y. Tang, Sensors Act. B: Chem. 2013, 185, 125-131; e) X. Hou, F. Zeng, F. Du, S. Wu, Nanotechnology 2013, 24, 335502; f) J. Wang, L. Long, D. Xie, Y. Zhan, J. Lumin. 2013, 139, 40-46; g) X. Qu, C. Li, H. Chen, J. Mack, Z. Guo, Z. Shen, Chem. Commun. 2013, 49, 7510-7512; h) X. Wu, H. Li, Y. Kan, B. Yin, Dalton Trans. 2013, 42, 16302-16310; i) C. Kar, M. D. Adhikari, A. Ramesh, G. Das, Inorg. Chem. 2013, 52, 743-752; j) F. Zheng, M. Wen, F. Zeng, S. Wu, Sensors Act. B: Chem. 2013, 185, 1012-1018.

[19] a) C. Liu, B. Peng, S. Li, C. -M. Park, A. R. Whorton, M. Xian, Org. Lett. 2012, 14, 2184-2187; b) C. Liu, J. Pan, S. Li, Y. Zhao, L. Y. Wu, C. E. Berkman, A. R. Whorton, M. Xian, Angew. Chem. Int. Ed. 2011, 50, 10327-10329; c) Z. Xu, L. Xu, J. Zhou, Y. Xu, W. Zhu, X. Qian, Chem. Commun. 2012, 48, 10871-10873; d) J. Liu, Y. -Q. Sun, J. Zhang, T. Yang, J. Cao, L. Zhang, W. Guo, Chem. Eur. J. $2013,19,4717-4722$.

[20] a) C. Wei, Q. Zhu, W. Liu, W. Chen, Z. Xi, L. Yi, Org. Biomol. Chem. 2013, 11, 479-485; b) C. Wei, L. Wei, Z. Xi, L. Yi, Tetrahedron Lett. 2013, 54, 6937-6939; c) X. -F. Yang, L. Wang, H. Xu, M. Zhao, Anal. Chim. Acta 2009, 631, 91-95.

[21] a) X. Cao, W. Lin, K. Zheng, L. He, Chem. Commun. 2012, 48, 10529-10531; b) T. Liu, Z. Xu, D. R. Spring, J. Cui, Org. Lett., 2013, 15, 2310-2313; c) Y. Liu, G. Feng, Org. Biomol. Chem. 2014, 12, 438-445; d) S. El Sayed, C. de la Torre, L. E. Santos-Figueroa, R. Martínez-Máñez, F. Sancenón, A. M. Costero, M. Parra, S. Gil, RSC Adv. 2013, 3, 25690-25693.

[22] a) A. R. Lippert, E. J. New, C. J. Chang, J. Am. Chem. Soc. 2011, 133, 10078-10080; b) H. Peng, Y. Cheng, C. Dai, A. L. King, L. B. Predmore, D. J. Lefer, B. Wang, Angew. Chem. Int. Ed. 2011, 50, 9672-9675; c) S. K. Das, C. S. Lim, S. Y. Yang, J. H. Han, B. R. Cho, Chem. Commun. 2012, 48, 8395-8397; d) Z. Wu, Z. Li, L. Yang, J. Han, S. Han, Chem. Commun. 2012, 48, 10120-10122; e) S. Chen, Z. -J. Chen, W. Ren, H. -W. Ai, J. Am. Chem. Soc. 2012, 134, 9589-9592; f) F. Yu, P. Li, P. Song, B. Wang, J. Zhao, K. Han, Chem. Commun. 2012, 48, 2852-2854; g) W. Xuan, R. Pan, Y. Cao, K. Liu, W. Wang, Chem. Commun. 2012, 48, 10669-10671; h) L. A. Montoya, M. D. Pluth, Chem. Commun. 2012, 48, 4767-4769; i) W. Sun, J. Fan, C. Hu, J. Cao, H. Zhang, X. Xiong, J. Wang, S. Cui, S. Sun, X. Peng, Chem. Commun. 2013, 49, 3890-3892; j) T. Saha, D. Kand, P. Talukdar, Org. Biomol. Chem. 2013, 11, 8166-8170; k) G. Zhou, H. Wang, Y. Ma, X. Chen, Tetrahedron 2013, 69, 867-870; 1) C. Yu, X. Li, F. Zeng, F. Zheng, S. Wu, Chem. Commun. 2013, 49, 403-405.

[23] a) L. E. Santos-Figueroa, C. Giméñez, A. Agostini, M. D. Marcos, F. Sancenón, R. Martínez-Máñez, P. Amorós, Angew. Chem. Int. Ed. 2013, 52, 13712-13716; b) E. Climent, A. Agostini, M. E. Moragues, R. Martínez-Máñez, F. Sancenón, T. Pardo, M. D. Marcos, Chem. Eur. J. 2013, 19, 17301-17304; c) A. Agostini, M. Milani, R. Martínez-Máñez, M. Licchelli, J. Soto, F. Sancenón, Chem. Asian. J. 2012, 7, 2040-2044; d) E. Climent, C. Giménez, M. D. Marcos, R. Martínez-Máñez, F. Sancenón, J. Soto, Chem. Commun. 2011, 47, 6873-6875; e) M. E. Moragues, J. Esteban, J. V. Ros-Lis, R. Martínez-Máñez, M. D. Marcos, M. Martínez, J. Soto, F. Sancenón, J. Am. Chem. Soc. 2011, 133, 15762-15772; f) E. Climent, A. Martí, S. Royo, R. Martínez-Máñez, M. D. Marcos, F. Sancenón, J. Soto, A. M. Costero, S. Gil, M. Parra, Angew. Chem. Int. Ed. 2010, 49, 5945-5948; g) E. Climent, M. D. Marcos, R. Martínez-Máñez, F. Sancenón, J. Soto, K. Rurack, P. Amorós, Angew. Chem. Int. Ed. 2009, 48, $8519-8522$.

[24] a) F. Kazemi, A. R. Kiasat, S. Sayyahi, Phosphorus, Sulfur Silicon Relat. Elem. 2004, 179, 1813-1817; L. Pang, D. Wang, J. Zhou, L. Zhang, X. Ye, Org. Biomol. Chem. 2009, 7, 4252-4266.

[25] J. C. Mathai, A. Missner, P. Kügler, S. M. Saparov, M. L. Zeidel, J. K. Lee, P. Pohl, Proc. Natl. Acad. Sci. USA 2009, 106, 16633-16638. 
[26] M. Hoffman, A. Rajapakse, X. Shen, K. S. Gates, Chem. Res. Toxicol. 2012, 25, 1609-1615. 